\section{Dari Kolektor Besi Tua Hingga Sosok Religius: Stereotip Orang Madura Melalui Humor ${ }^{1}$}

Herlianto A.

Department of Languages and Literatures Universitas Gadjah Mada herlyzalembu@yahoo.com

\begin{abstract}
This research aims to describe the stereotype of Madurese through humor. Humor and stereotyping are two inseparable concepts, especially ethnic humor. Madurese humors are discourses that are not neutral; there are interests and intentions behind every discourse of humor that is set. Ethnic humor is formed by exploring the weaknesses of other ethic groups especially related to the character of the ethnic. This is a form of speaker superiority about the ethnic. This study uses a social paradigm, qualitative approach, and interviewing and observing data collection methods. Source of the data comes from documents and informants. Data were analyzed by applying critical discourse analysis of van Dijk. This theory divides a discourse into three part: text, social cognition and context. The results showed at least seven of Madurese stereotypes through humor. Of the seven, it is divided into two categories, which are based on the job: scrap metal collectors, female herbalist, religious man, and satay seller; and based on the characters, namely: dumbness, cleverness, and rudeness. This critical research proves the stereotype through humor is an attempt to perpetuate the culturally alienated position of Madurese race.
\end{abstract}

Keywords: humor Madura; stereotip; wacana

\title{
PENGANTAR
}

Humor Madura yang menjadikan orang Madura sebagai pemeran utama dalam cerita sudah dikenal di kalangan masyarakat nusantara, namun masih dianggap sebatas hiburan atau lucu-lucuan untuk menimbulkan tawa. la dinyatakan pada momen-momen informal maupun formal semata untuk mengatasi kejenuhan komunikasi. Padahal sebagai wacana, humor merupakan medan yang menyiratkan makna tertentu yang digunakan untuk maksud tertentu pula. Artinya, humor tidak pernah netral sebagai sebatas humor itu sendiri, melainkan selalu menyiratkan representasi dari suatu kelompok sosial yang dijadikan objek berhumor.

Jika objek berhumornya adalah orang Madura, maka sebetulnya penutur humor sedang menggambarkan atau dalam bahasa yang lebih tepat "menstereotipkan" komunitas Madura. Stereotip dalam hal ini ialah gambaran tipikal yang hadir dalam pikiran tentang suatu kelompok sosial (Dovidio, Hewstone, Glikc \& Esses, 2008: 7). Misalnya, penutur yang sedang mengkisahkan humor penjual sate asal Madura, kolektor besi tua, penjual jamu wanita, sikap religius atau fanatisme agama orang Madura tidak sekedar bermaksud melucu. Tetapi juga untuk menetapkan stereotip tentang Madura yang melekat diingatan masyarakat umum. Orang Madura dicitrakan sedemikian rupa dalam humor sehingga siapapun yang mempersepsinya seketika memiliki gambaran tertentu.

Beberapa peneliti seperti Raskin (1984), Maio, Olson dan Bush (2000) dan Mulder \& Nijholt (2002) berargumen bahwa humor adalah medan pertunjukan superioritas sosial antara penutur humor pada yang dihumorkan. Objek humor selalu menjadi pihak yang terendahkan status sosialnya atau mereka yang kalah secara sosial terhadap si pencerita humor. Jenis humor inilah yang disebut humor etnis (ethnic humor). Menurut Raskin humor etnis akan mengeksploitasi sisi

\footnotetext{
${ }^{1}$ Artikel ini merupakan bagian dari tesis penulis di Magister Linguistik Universitas Gadjah Mada (UGM)
} 
lemah kelompok etnis tertentu seperti kebodohan (dumbness), kekikiran (stinginess), kecerdikan (deceitfulness), kelicikan (cunningness). Citra-citra ini yang kemudian distereotipkan melalui cerita humor.

Pendapat senada dinyatakan oleh Wijana (2015) dalam penelitiannya tentang humor etnis di Indonesia. Hanya saja perbedaannya, menurut Wijana, meskipun humor etnis menyasar kelemahan etnis lain tetapi bukan untuk merendahkan kelompok etnis tersebut melainkan, sebaliknya, untuk menciptakan harmonisasi demi meningktkan keeratan sosial di antara kelompok etnis. Pandangan Wijana cenderung ke arah positif dalam melihat fungsi humor. Namun, apakah benar demikian adanya? Beberapa penelitian di luar Indonesia menunjukkan hal yang sebaliknya, bahwa humor etnis justru membuat jarak sosial semakin melebar bahkan ada kecenderungan rasis terutama etnis mayoritas terhadap minoritas. Artinya fungsi humor etnis tetap bernuansa superioritas atau cenderung negatif. Maio dkk. (1997), Mickes, Walker, Parris, Mankoff dan Christenfeld (2011), Gogova (2016), Wolfers, File dan Schnurr (2017), Sierra (2018), Miller, O'Dea, Lawless dan Saucier (2019), dan Sinkeviciute (2019) adalah beberapa peneliti yang berada dalam pandangan ini. Dengan demikian ada dua pandangan tentang fungsi humor etnis yaitu sebagai harmonisasi (positif) dan superioritas (negatif). Pertanyaannya bagaimana dengan humor Madura?

Beberapa peneliti telah melakukan kajian terhadap humor Madura. Hanya saja mereka tidak menyentuh pada bagaimana humor etnis Madura difungsikan. Misalnya, Hasan (2007) menyatakan bahwa Madura merupakan sarana untuk ajang saling menasehati dan mempertahankan moral sosial dan agama. Febrianti, Sukatman dan Husniah (2014) menyelidiki apa yang disebut "tebak-tebakan" dalam tradisi Madura yang biasanya menjadi salah satu media untuk berhumor. Sayangnya, penelitian ini hanya menyorot secara etnografis sehingga temuannya hanya menyatakan secara naratif bahwa teka-teki Madura masih ada, tidak mengorek lebih jauh tentang adanya stereotip di situ.

Hestiyana (2016) hanya meneliti bentuk-bentuk kebahasaan humor Madura. Temuannya menyatakan bahwa humor Madura dibentuk melalui pelanggaran atas prinsip kerjasama komunikasi. Dalam hal ini dia menerapkan kajian pelanggaran maksim (maxim block) kerjasama dalam pandangan Grice. Selain itu, Efawati (2018) meneliti bagaimana kesalahpahaman publik terhadap karakter orang Madura yang dianggap keras. Menurutnya, humor Madura justru menunjukkan sebaliknya yaitu bahwa orang Madura memiliki karakter berpikiran luas, terbuka, keyakinan yang tinggi, teguh dalam berprinsip, dan cerdas dalam mengemukakan alasan-alasan atas tindakan yang dilakukan.

Kalau ditelisik dari beberapa penelitian ini, semuanya tidak kritis terhadap bagaimana wacana humor Madura difungsikan. Memang metode pengkajian mereka bukan kajian wacana (kritis) sehingga mengabaikan stereotip orang Madura yang selama ini mengemuka di dalam humorhumor Madura. Mereka sebagaimana Wijana cenderung berpandangan positif tentang humor Madura. Artikel ini mengkaji secara berbeda dari beberapa riset humor Madura tersebut, yaitu dengan menggali secara lebih kritis dari perspektif analisis wacana van Dijk tentang stererotip orang Madura yang terdapat dalam humor. Beberapa problem yang dibahas dalam riset ini di antaranya jenis-jenis stereotip orang Madura dalam humor dan bagaimana stereotip itu dimungkinkan jika dikaitkan dengan kondisi identitas kebudayaan Madura.

\section{ANALISIS DAN PEMBAHASAN}

Data riset ini melalui wawancara dan dokumen humor di antaranya Humor Orang Madura ditulis Heri Mulyono Cahyo, dkk, Kelakar Madura Buat Gus Dur oleh Sujiwo Tejo, dan Humor Madura Untuk Penyegar Jiwa ditulis H. Musa, MBA. Analisis terhadap data itu ditemukan beberapa stereotip orang Madura. Ada sebanyak delapan stereotip yang diklasifikasi. Sejumlah stereotip ini dipilah pada dua kategori, yaitu stereotip dikaitkan dengan profesi atau pekerjaan dan yang dikaitkan dengan karakter atau watak masyarakat Madura. Kategori pertama mencakup kolektor besi tua, penjual jamu wanita, penjual sate dan tukang cukur. Sementara Ketegori kedua di antaranya berkarakter konyol, cerdik, keras, dan religius. 


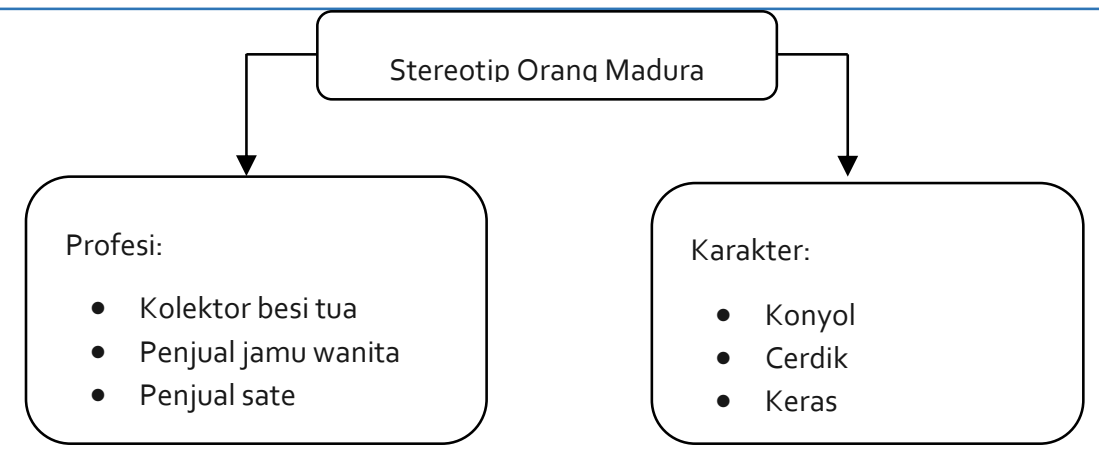

\section{Stereotip Berdasarkan Profesi}

\section{a. Kolektor Besi Tua}

Kondisi perekonomian masyarakat Madura terbilang tidak terlalu berkembang di banding daerahdaerah lain di Jawa Timur terutama Surabaya. Mata pencaharian orang Madura tetap bertumpu di sektor pertanian yang masih tradisional. Kondisi ini membuat mereka berpikir lain untuk menambah penghasilan sehari-hari. Salah satunya dengan mengumpulkan besi-besi bekas yang sudah tidak dipakai atau biasa dikenal dengan "besi tua". Bahan-bahan tak terpakai itu dijual sebagai bahan daur ulang. Hasilnya tentu untuk memenuhi kebutuhan hidup sehari-hari. Kendati begitu, belumlah cukup untuk menopang kehidupan perekonomian mereka, sehingga sebagian dari mereka memilih merantau ke daerah-daerah lain, terutama kota-kota besar di Jawa. Di perantauan orang Madura juga tetap menjadi kolektor besi tua, sebagian ada yang sukses menjadi pengusaha bahan bekas ini. Cara bertahan hidup ini membuat mereka distereorip kolektor besi tua, lalu berkembang humor Madura dengan besi tua sebagai topiknya. Lihat humor berikut.

\section{(1) Jembatan Madura}

Suatu hari kepala proyek pembangunan jembatan Suramadu mengadakan rapat dengan masyarakat Madura tentang rangka jembatan.
Kepala Proyek : jembatan yang menghubungkan Madura-Surabaya akan dibuat dari beton bertulang supaya tahan hingga 50 tahun
Orang Madura : tidak setuju kalau dari beton, kami mohon dibuat dari besi seluruhnya.
Menteri : apa alasan saudara?
Orang Madura : Kalau dibuat dari besi, setelah 50 tahun kan jadi besi tua bisa dipotong-potong dan dijual kiloan.

\section{b. Peramu Jamu Wanita}

Orang Madura memiliki tradisi minum jamu atau ramuan, terutama jamu yang berasal dari tanamantanaman obat alamiah, seperti kunyit, jahe, pinang, sirih, dst. Bahan-bahan itu biasanya diolah sendiri oleh mereka, lalu secara rutin dimimum. Minum jamu bagian dari cara hidup mereka untuk menjaga tubuh tetap sehat dan stamina terus stabil, mengingat orang Madura adalah pekerja keras. Mengkonsumsi jamu tidak hanya menjadi tradisi kaum lelaki Madura tetapi juga kaum perempuan. Namun kemudian ramuan yang sangat terkenal adalah ramuan untuk kaum perempuan yang diyakini dapat menambah dan memberikan keintiman yang lebih nikmat bagi pasangan suami istri. Kini banyak orang meyakini ramuan perempuan Madura sangat bermanfaat bagi keharmonisan keluarga. Lihat humor berikut.

\section{(2) Penjual Jamu Wanita}

Suatu hari orang Madura menjual jamu khusus perempuan di pasar Turi Surabaya. Datanglah seorang pembeli ingin tahu khasiatnya.

Orang Madura : : jamu

Pembeli : apa benar jamunya bikin suami semakin sayang pak? 
Orang Madura : beh.. Kalau jamu Madura tidak diragukan lagi, buk.

Pembeli : seperti apa buktinya?

Orang Madura : perempuan yang tidak minum jamu Madura kalau diminta buat kopi maka sendoknya yang mengaduk kopi dalam gelas. Tetapi perempuan yang minum jamu Madura kalau buat kopi bukan sendok yang mengaduk gelas, tapi gelas yang mengaduk sendoknya.

Yang ingin ditampilkan dari humor ini adalah bagaimana pengaruh jamu Madura terhadap perempuan dengan menggunakan metafor sendok dan gelas.

\section{c. Penjual Sate}

Sate Madura merupakan jenis sate yang banyak diminati masyarakat sebagai menu makan. Orang Madura yang berada di perantauan biasanya bertahan hidup atau memang mencari kerja dengan menjual sate. Mereka biasanya berjualan sate dengan dua model, model kaki lima yang berpindahpindah dari satu ke tempat lain dan model menetap dengan membuka warung makan permanen. Bagi sebagian orang rasa sate Madura istimewa. Sehingga penjual sate identik dengan orang Madura.

\section{(3) Sate Bangsat}

Matnawi, orang Madura yang baru merantau di Jakarta tidak mendapat pekerjaan kantoran yang diinginkan. Akhirnya dia menyambung hidup dengan bakatnya, yaitu jual sate.

$$
\begin{aligned}
& \text { Matnawi : te... sate.... Te.....sate..... (datanglah orang Betawi memanggil) } \\
& \text { Orang B etawi : } \text { bang }_{\prime \prime} \text {, sate }{ }_{\prime \prime \prime \prime} \text {, bagsat }, \text {, bangsat... } \\
& \text { Matnawi setengah tersinggung, hatinya dongkol, berputar balik menuju pembeli. } \\
& \text { Orang Betawi : sate seporsi tidak pedas bang. } \\
& \text { Setelah itu Matnawi bertemu temannya, Saru'ding, penjual sate Madura lainnya. } \\
& \text { Matnawi : orang Jakarta itu tidak sopan, masak saya dipanggil "bangsat". } \\
& \text { Saru'ding : bukan tak sopan Mat, bangsat itu "abang sate" }
\end{aligned}
$$

\section{d. Tukang Cukur}

Di kota-kota besar seperti Surabaya, Malang, Jakarta, Bali dan Yogyakarta selalu ditemukan tempattempat potong rambut yang dikelola orang Madura. Umumnya, pada sisi depan bangunan potong rambut itu bertuliskan "Potong Rambut Madura". Nama ini untuk menegaskan bahwa tempat potong rambut itu adalah asli orang Madura. Tukang potong rambut adalah profesi yang tidak terlalu memberatkan bagi orang Madura, karena tidak membutuhkan banyak persyaratan seperti pendidikan dari jenjang tertentu. Mereka hanya cukup latihan beberapa model potong rambut yang tidak memerlukan waktu lama. Artinya, menjadi pemotong rambut dipilih lantaran cukup bagi orang Madura untuk bekerja dan dapat bertahan hidup di tanah rantau. Hal ini terkait erat dengan kondisi perekonomian di Madura yang tidak terlalu baik.

\section{(4) Tukang Cukur}

$$
\begin{aligned}
\text { Langganan } & \text { : } \begin{array}{l}
\text { motongnya jangan terlalu pendek, pak. Di bagian samping jangan } \\
\text { terlalu tipis. Bagian belakang jangan terlalu tinggi. }
\end{array} \\
\text { Tukang cukur } \quad \text { : } & \text { saya jadi tukang cukur sudah } 25 \text { tahun. Bapak jangan mengajari } \\
& \text { saya. Saya apakan saja bapak harus nurut. Kalau nggak bisa dia saya } \\
& \text { tinggal. }
\end{aligned}
$$

Lagganan : boo, baru dapat separu mau ditinggal. Kan pitak kepala saya. 
Herlianto A.

\section{Stereotip Berdasarkan Karakter}

a. Bertingkah Konyol

Secara pendidikan, Madura terbilang cukup tertinggal dibanding daerah-daerah lain di Jawa Timur. Di daerah-daerah pedalaman Madura, masih ditemukan banyak anak-anak usia belasan tahun yang tidak mengenyam sekolah. Atau sekolah tetapi putus di tengah jalan. Beberapa faktor yang menjadi penyebab ketertinggalan ini adalah kesadaran akan pendidikan belum terbangun dengan baik selebihnya soal biaya sekolah. Karena itu, sumber daya manusia Madura digolongkan kelas C, berbeda dengan Jawa dan Bali kelas A. Realitas ini yang membuat kisah-kisah humor merepresentasikan betapa orang Madura tidak memiliki wawasan yang cukup, terutama berkaitan dengan ruang publik, seperti di kantor atau transportasi umum.

\section{(5) Merokok Dalam Bus}

Sebuah bus macet 2 jam di kawasan Porong Sidoarjo. Seorang Madura nekat merokok dalam bus tersebut. Ibu dengan membawa bayi protes.

Ibu : pak kok merokok, ini bus ber-AC.

Orang Madura : saya tidak tahan lama-lama begini tidak merokok

Ibu : : kalau bapak merokok, si kecil ini tidak tahan

Orang Madura : iya.. iya..

Si bayi menangis, sang ibu menenangkan dengan menyusuinya

Orang M : abbo.. Mbak sampeyan kok gitu

Ibu : : lho anak ini nangis, lupa tidak bawa botol

Orang M : nggak boleh mengeluarkan anggota badan (sambil menunjuk pada kaca bus yang bertuliskan "DILARANG MENGELUARKAN ANGGOTA BADAN"

\section{b. Bertingkah Cerdik}

Keterbatasan apapun tidak menjadi alasan bagi orang Madura untuk menyerah menjalani hidup. Mereka terbiasa berusaha keras dan berupaya "mengakali" sesuatu yang terlihat tidak mungkin menjadi mungkin. Orang Madura selalu punya cara untuk mengubah keadaan yang sulit menjadi mudah, meskipun usahanya tidak selalu berhasil. Banyak kajadian-kejadian yang membuat orang Madura terjepit tetapi kemudian dapat dijalani dengan baik. Stereotip ini biasanya dinyatakan dengan ungkapan "cerdik" yang maknanya lebih bernuansa negatif. Cerdik berkencederungan mengakali dengan sedikit berbau licik dan triki ketimbang cerdik dalam arti kreattif berkarya.

\section{(6) Sapi Jawa}

Suatu hari orang Madura menuntun dua puluh ekor sapi di Kota Surabaya. Datanglah polisi menegur.

Polisi : kau ini bawa sapi segini banyak di jalan raya. Lihat lalu lintas jadi macet. Dasar Madura!.

Orang Madura : siap pak, betul pak saya orang Madura. Tapi bapak perlu tahu sapisapi yang bandel ini adalah sapi Jawa

\section{c. Keras}

Ketika menyebut orang Madura, keras adalah salah satu karakter yang langsung menempel disetiap pikiran orang. Keras dalam hal ini dapat dimaknai beragam, mulai keras karena tindakan secara fisik, atau berkaitan dengan prinsip-prinsip orang Madura yang tidak mudah diubah. Yang kedua ini lebih dekat dengan watak. Susah diberikan nasihat hingga keras dalam bertutur kata. Salah satu kekerasan fisik yang identik dengan orang Madura adalah carok. Carok dianggap salah satu tradisi yang menyimbolkan watak keras orang Madura. Walaupun sebetulnya tradisi ini tidak bisa sembarangan karena ada aturan-aturannya yang mesti diikuti sebelum carok. Tetapi belakangan memang 
disalahgunakan adat ini. Berbagai citra keras ini kemudian mengendap dalam beberapa humor orang Madura.

\section{(7) Tidak Pernah Tersinggung}

Tono : :saya dengar, orang Madura temperamennya keras dan mudah tersinggung.

Tole : salah, ton. orang Madura itu tidak pemah tersinggung oleh siapa pun.

Tono : ah, yang benar saja.Tole : : benar karena sebelum sempat tersinggung, lawannya sudah tergeletak kena clurit.

\section{d. Religius}

Tentang agama, masyarakat Madura tidak diragukan lagi. Bagi mereka agama (Islam) paling utama dalam hidup. Jalan agama adalah jalan yang mesti ditempuh orang Madura dalam hidupnya. Mayoritas mereka beragama Islam, karena itu pesantren memiliki peran penting bagi orang Madura sebagai tempat untuk menimba ilmu agama. Ada ribuan pesantren yang tersebar mulai dari kabupaten Sumenep hingga Bangkalan, baik yang besar maupun kecil. Sejak kecil anak-anak Madura sudah biasa mondok di pesantren untuk memperdalam ilmu agama (Islam). Keadaan ini yang membuat agama (Islam) tidak bisa ditawar lagi. Menariknya, cita-cita agama orang Madura di dunia adalah naik haji. Haji merupakan perjalanan ibadah yang sangat diimpikan orang Madura. Karena itu, ada kisah-kisah humorik Madura berkaitan dengan haji.

\section{(8) Gerah}

Suatu ketika ada orang Madura pergi melaksanakan ibadah umroh. Ketika tiba di kamar hotel, dia merasa sangat kegerahan. Setelah dicari penyebabnya, dia mendapati AC kamar mati. Segera dia melapor ke petugas hotel.

Tapi dia kebingungan bagaimana harus menjelaskannya, karena tak bisa berbahasa Arab.

"Hadza, innalillahi wa innailahi raojiun" katanya matap.

Sang resepsionis bingung apa yang dimaksud orang Madura itu

"Ana nar.. nar..." lanjut orang Madura tadi sambil mengibaskan koran ke tubuhnya.

Akhirnya sang resepsionis tersebut paham.

\section{PEMBAHASAN}

Pembahasan artikel ini menggunakan pendekatan analisis wacana van Dijk. Dia menyatakan bahwa suatu teks termasuk humor selalu mengandung atau merepresentasikan ideologi (pandangan) tertentu, artinya teks selalu terikat pada kesadaran sosial dan konteks. Maka, untuk mengetahui muatan dibalik wacana itu analisis ini harus mengaitkan tiga hal yaitu teks, kognisi sosial, dan konteks sebagaimana dirumuskan van Dijk.

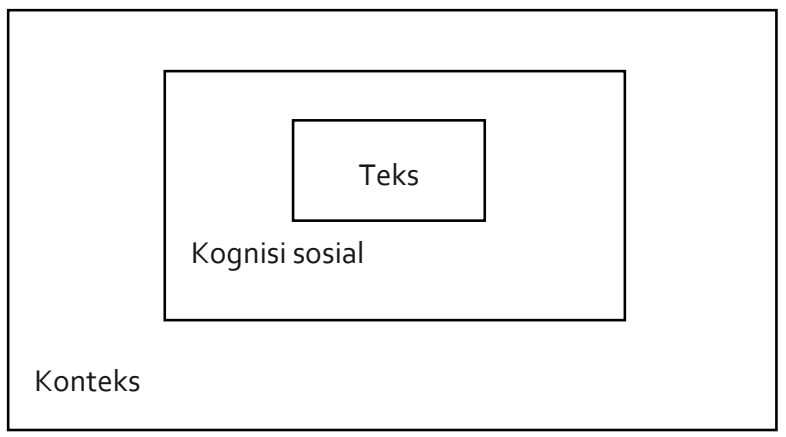


Herlianto A.

Setelah itu menafsir stereotip tentang orang Madura yang bersemayam di balik humor. Hal ini untuk menunjukkan bahwa humor sebagai wacana menyembunyikan stereotip sekaligus menunjukkan superioritas.

\section{Kognisi Sosial}

Kognisi sosial adalah proses sejarah yang menjembatani antar konteks (di luar bahasa) dengan teks (van Dijk, 2009: 29). Kognisi sosial membentuk kesadaran mental masyarakat, dapat juga berupa memori kolektif, atau cara pandang masyarakat terhadap orang Madura yang sudah dibentuk selama periode historis tertetu. Pemahaman publik tentang Madura bukanlah suatu kesadaran yang didapat dalam jangka satu hari atau hitungan bulan saja. Melainkan suatu pemahaman yang terjalin dalam hitungan abad bahkan milenium. Karena itu, proses historis masyarakat Madura menentukan bagaimana kedasaran kolektif orang tentang Madura. Madura memiliki sejarah tidak sebesar kebudayaan Jawa, dalam arti kekuasaannya. Bahkan boleh dibilang Madura merupakan suatu kawasan yang terus dipimpin Jawa. Sejak kemegahan kerajaan Singosari abad ke 12, Majapahit, Demak, Mataram bahkan hingga hari ini.

Di era kerajaan Singosasri, Madura menjadi tempat pengasingan sosok Banyak Wide (dikenal Arya Wiraraja), seorang pengatur siasat perang raja Singosasri, Kertanagara. Saat itu Madura dikenal dengan "Tanah Merah" yang berarti tanah gersang. Berdirinya, Majapahit juga semakin membuat Madura bergantung pada Jawa (Adji \& Achmad, 2015). Begitu kerajaan Demak yang didirikan oleh Raden Patah berkuasa di abad 15, Madura kembali menjadi kawasan yang harus tunduk. Salah satu yang penting dalam hal ini adalah Islamisasi di Madura. Mengingat Demak merupakan kerajaan Islam. Madura menjadi daerah yang turut diislamkan. Sunan Ampel berperan besar bagi Islamisasi Madura. Sejak itulah Islam menjadi agama "Impor" bagi Madura yang terus dipegang kuat hingga hari ini.

Kemudian, abad ke 17, Raden Trunojoyo sempat berupaya melakukan perlawanan terhadap Mataram yang dipimpin oleh Amangkurat I dan II kala itu. Tetapi lagi-lagi dengan mudah ditumpas dan tetap harus tunduk pada Jawa. Jadi, secara historis Madura tidak pernah mengalami kemerdekaannya yang sejati sebagai suatu bangsa (etnis) di Nusantara (Ricklefs, 2008). Sebab itu, Madura selalu merasa lebih rendah dari Jawa secara kebudayaan. Ada satu tradisi yang menunjukkan betapa Madura berada satu level di bawah budaya Jawa, yaitu tradisi "toron" (turun).

Orang Madura yang pergi ke Jawa disebut "naik", kemudian saat dia balik ke Madura disebut "toron". Tradisi ini menunjukkan bukan berarti bahwa letak geografis Jawa lebih tinggi dari Madura. Lebih dari sekedar itu, bahwa kebudayaan Jawa dipandang lebih tinggi dari Madura. Ada kemajuan atau keberadaban di Jawa yang ingin "dinaiki" orang Madura (Djakfar, 2012). Tradisi toron merupakan perlambang bahwa Madura berada di kelas C. Begitulah kognisi sosial tentang Madura. Fakta-fakta kesejarahan inilah yang turut membentuk kesadaran publik tentang kebudayaan, tradisi, dan bahkan sosok orang Madura. Sehingga etnis Madura dipersepsi berada di bawah Jawa.

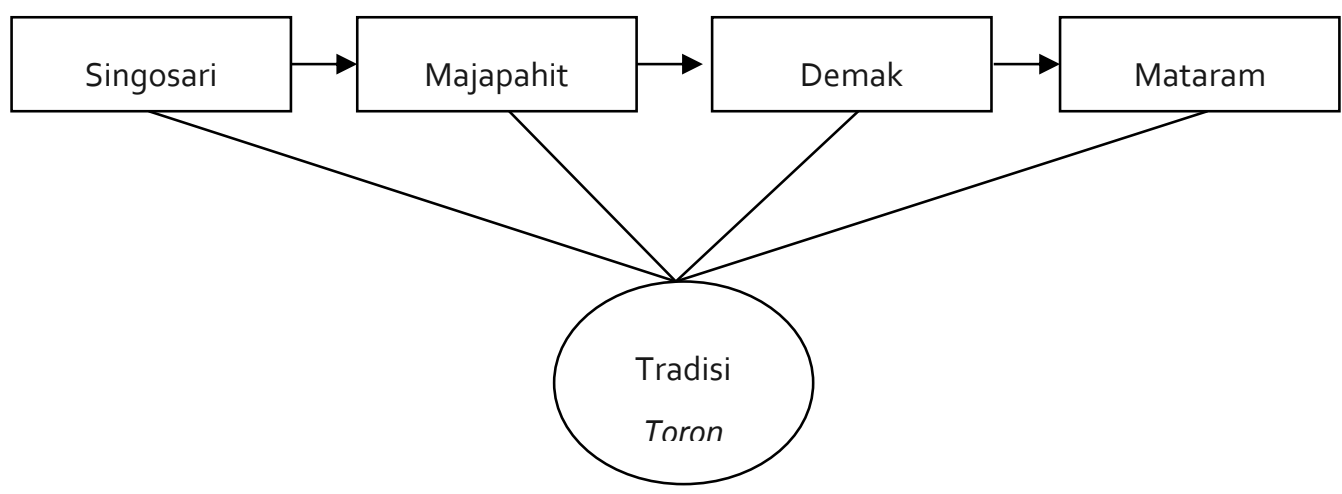




\section{Struktur Teks Humor:}

\section{a. Struktur Makro:}

Struktur ini adalah topik dan tema yang dipilih pada setiap humor yaitu apa yang menjadi kondisi riil atau yang dialami sehari-hari oleh masyarakat Madura dalam situasi sosial dan budayanya. Misalnya, jual sate, mengoleksi besi tua, membawa sapi, jamu wanita, agamis, carok, dst. Semua itu adalah aktivitas normal orang Madura. Dengan topit-topik itu menunjukkan bahwa humor Madura memang dimaksudkan untuk menggambarkan dan membentuk image (stereotip) tertentu tentang Madura berdasarkan kondisi nyata mereka.

\section{b. Superstruktur:}

Orang Madura ditipikalisasi sedemikian rupa ketika berinteraksi dengan lawan bicaranya. Dalam humor-humor di atas, peran orang Madura ditonjolkan keterlibatannya. Tetapi sebagai sosok yang memerankan hal yang "sangat stereotyping", misalnya sosok yang tidak bisa berbahasa Arab (humor 8), ugal-ugalan membawa sapi di jalan raya (humor 6), tidak paham akronim "bangsat" (humor 3), inisiator menjual besi tua (humor 1), dst. Beberapa citra ini melekat pada tokoh humor yang ternyata orang Madura.

\section{c. Struktur Mikro:}

Struktur mikro yang berkaitan dengan pola bagaimana tuturan atau ungkapan-ungkapan yang digunakan, termasuk pilihan ungkapan. Pernyataan-pernyataan yang dilimpahkan untuk menandai orang Madura lebih banyak berasosiasi negatif. Misalnya "Kalau dibuat dari besi, setelah 50 tahun kan jadi besi tua" (humor 1), pernyataan ini seolah-olah orang Madura bermaksud mengambil besi itu di masa yang akan datang, sekalipun itu bukan miliknya. Contoh lain, "Ana nar.. nar..." lanjut orang Madura tadi" (humor 8), pernyataan ini menandakan orang Madura yang tidak bisa berbahasa Arab tetapi kemudian memaksakan diri berbicara dengan ungkapan yang sama sekali salah. Lainnya lagi, "lihat lalu lintas jadi macet. Dasar Madura" (humor 6). Orang Madura kemudian menjadi penyebab dari ketidak lancaran lalu lintas. Bahkan tegas menggunakan ungkapan yang sangat pedas yaitu: "Dasar Madura"

\section{Konteks}

Konteks berhubungan dengan situasi atau lingkungan (kekinian), atau berupa fenomena dan peristiwa tertentu yang melingkupi atau mendahului suatu teks (van Dijk, 2008: 4). Hal ini bisa berupa kondisi riil masyarakat Madura. Dalam hal ini, diurai konteks-konteks yang membentuk punch line pada humor Madura yang memungkinkan konteks ini sebagai stereotip. Masing-masing humor yang ditemukan menggunakan konteks riil kehidupan sosial, budaya, dan ekonomi masyarakat Madura. Katakanlah humor tentang besi tua, di mana yang dijadikan konteks berhumor adalah pembangunan jembatan Suramadu. Jembatan Suramadu yang mestinya menjadi kebanggaan orang Madura, tetapi diplesetkan dalam humor kolektor besi tua yang menjadi kebiasaan orang Madura. Begitu juga dengan sapi pada humor "Sapi Jawa". Konteks yang digunakan adalah kondisi agraris Madura yang mana bertani dan berternak sapi masih menjadi salah satu sumber penghidupannya.

Pada humor (8), mengambil konteks keagamaan orang Madura. Seting yang digunakan adalah ibadah umroh, Mekkah. Sudah mafhum bahwa naik haji merupakan cita-cita semua orang Madura sebagai mayoritas muslim. Mereka jika ditanya cita-cita biasanya menjawab ingin naik haji. Sebab itu haji menjadi penting sebagai penanda sikap agama mereka. Begitu juga pada humor (3), ini adalah kondisi riil masyarakat Madura terutama yang berada daerah perantauan. Mereka mempertahankan hidup dengan berjualan sate. Dan terakhir adalah pembunuhan yang biasanya diasosiasikan dengan carok juga dijadikan konteks untuk menunjukkan bagaimana karakter keras dapat diidentikkan dengan orang Madura sebagaimana ditunjukkan humor (7).

Pertautan antara teks, kogisi sosial, dan konteks dalam humor Madura terhadap stereotip orang Madura dapat digambarkan dengan diagram dibawah ini. 


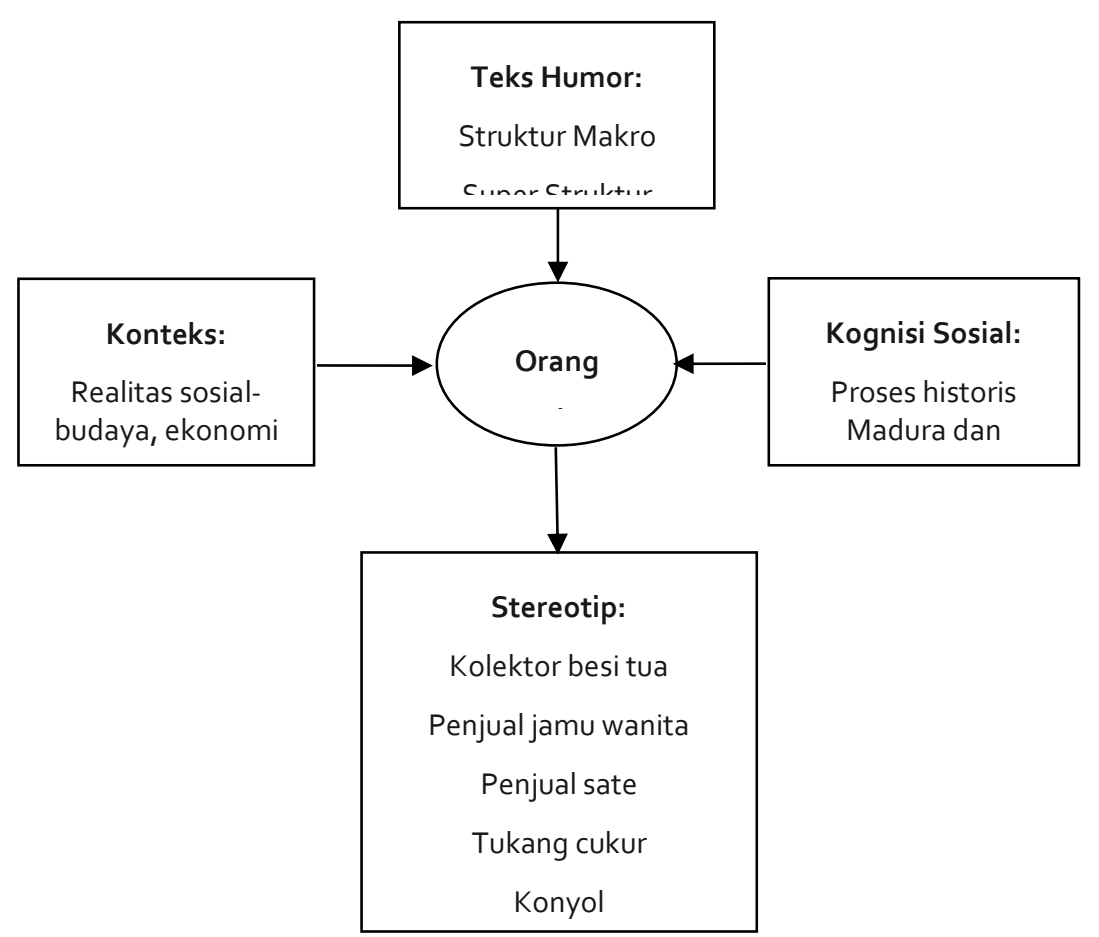

Melalui pengkajian secara kritis atas teks, kognisi sosial, dan konteks terhadap humor-humor Madura, maka dapat dipahami bahwa humor-humor tersebut dalam rangka melestarikan suatu stigma atas orang Madura yang sudah tergelar sejak zaman kerajaan pra modern hingga modern saat ini. Jadi pembacaan wacana kritisnya adalah, ada ideologi (pandangan) berupa stereotip budaya atas masyarakat Madura yang sebetulnya tetap ingin menunjukkan bahwa Madura merupakan tradisi yang masih rendahan dan tertinggal.

Pembacaan ini yang kemudian terus melanggenggkan stereotip orang Madura saat berada dan berinteraksi dengan komunitas dan budaya-budaya lain. Humor, sebagaimana teori superiotas menyatakan, memang sebagai satu mode yang cukup efektif untuk merendahkan sosok atau komunitas yang menjadi objek humor itu sendiri. Jadi ia adalah medan ideologisasi atas suatu masyarakat tertentu yang memang disembunyikan. Menariknya, humor-humor Madura tidak hanya sebagai keberlanjutan atas teralienasinya orang Madura tetapi juga sebagai stereotip yang berdampak secara sosial ketika orang Madura berada di ruang publik atau ketika berinteraksi secara publik. Singkatnya, humor yang bernuansa superiotas berkait erat dengan stereotip suatu sosok invidu atau komunitas. Dan inilah yang ditunjukkan di dalam penelitian ini pada humor-humor Madura.

\section{KESIMPULAN}

Humor tidak sesederhana yang dipikirkan yaitu sebatas hiburan atau lelucon. Lebih dari itu, ada makna yang disembunyikan dibalik setiap humor yang dinyatakan. Lebih-lebih humor berkaitan dengan etnisitas. Humor turut berfungsi sebagaimana wacana, yang berarti ada makna dan maksud dibalik setiap humor yang dinyatakan. Analisis wacana kritis yang telah dilakukan pada paper ini telah membuktikan hal itu. Bahwa, humor berisi maksud superiotas dari penuturnya. Menariknya, superioritas itu bertali-temali dengan stereotip suatu komunitas yang dijadikan obejk berhumor.

Analisis wacana kritis ala van Dikj memberikan perangkat yang cukup untuk mengkaji elemenelemn eksternal yang diurutkan dari elemen internal wacana dalam hal ini humor. Sehingga makna dan maksud berikut stereotip yang dibangun secara tersembunyi dengan kedok berhumur dapat diungkap. Tetapi bisa jadi ada perangkat analisis lain yang lebih memungkinkan untuk itu. Karena itu, bagi peneliti selanjutnya bisa dilakukan itu dengan harapan hasilnya lebih presisi dan akurat. 


\section{DAFTAR RUJUKAN}

Adji, Krisna Bayu \& Achmad, Sri Wintala. 2015. Senjakala Majapahit: Menguak Sejarah Dan Kebusukan Politik Majapahit. Yogyakarta: Araska Publisher

Cahyo Heri Mulyo. 2013. Humor Orang Madura. Malang: Penerbit Digital Pustaka Hanan

Djakfar, Muhammad. 2012. Tradisi Toron Etnis Madura: Memahami Pertautan Agama, Budaya, dan Etos Bisnis. Jurnal el-Harakah; Vol.14, No. 1. Hal. 34-50

Dovidio John F, Hewstone Miles, Glick Peter, Esses Victoria M, 2008. Prejudice, Stereotyping and Discrimination: Theoretical and Empirical Overview. The SAGE Handbook.

Efawati, Rifa. 2018. Karakteristik Budaya Madura Dalam Humor. Al-Iman: Jurnal Keislaman dan Kemasyarakatan; Vol. 2, No. 1, Hal. 407-416.

Febriayanti, Yustika, Sukatman, Husniah, F. 2014. Teka-Teki Dalam Tradisi Lisan Madura: Kajian Etnografi. Artikel Ilmiah Mahasiswa Universitas Jember.

Gogova, Lenka. 2016. Ethnic Humor in A Multicultural Society. De Gruyter, Hal 12-24. doi: 10.1515/aa2016-0006.

Hasan, Zainul. 2007. Tawashow Ala Madura. Karsa; Vol. XI No. 1, Hal. 78-88.

Hestiyana. 2016. Pelanggaran Prinsip Kerja Sama Dalam Humor Madura. Totobuang; Vol. 4, No. 2, Hal. 257-269. doi:http://dx.doi.org/10.26499/ttbng.v4i2.24

Maio, Gregory R, Olson, James M \& Bush, Jacqueline E. 1997. Telling Jokes That Disparage Social Group: Effects on The Jokes Teller's Stereotype. Jurnal of Applied Psichology.

Mickes, L, Walker, D.E, Parris, J.L, Mankoff, R, Christenfeld, N.J.S. 2011. Who's Funny: Gender Streotype, Humor Production, and Memory Bias. Psychon Bull Rev.

Miller, S.S, O’Dea, C.J., Lawless, T.J, \& Saucier, D.A. 2019. Savage or Satire: Individual Differences in Perceptions of Disparaging and Subversive Racial Humor. Personality and Individual Differences, Hal. 142, 28-41.

Mulder, M.P \& Nijholt, A. 2002. Humor Research: State of The Art. University of Twente: CTIT Technical Report Series.

Musa, MBA. 2004. Humor Madura Untuk Penyegar Jiwa. Jakarta: Kelompok Penerbit Gema Insani.

Raskin, Victor. 1984. Semantic mechanism of humor. Canada: Reidel Publishing Company.

Ricklefs, Merle C. 2008. Sejarah Indonesia Modern 1200-2008. Jakarta: Serambi

Sierra, S. 2018. Linguistic and Ethnic Media Stereotypes in Everyday Talk: Humor and Identity Construction Among Friends. Journal of Pragmatics, 30, Hal. 1-14. doi: 10.1016/j.pragma.2018.09.007

Sinkeviciute, V. 2019. The Interplay Between Humour and Identity Construction: From Humorous Identities to Identity Constructed Through Humorous Parctices. Journal of Pragmatics, 30, Hal. 1-5. doi: 10.1016/j.pragma.2019.07.005

Tedjo, Sujiwo. 2018. Kelakar Madura Buat Gus Dur. Tangerang Selatan: Imania

van Dijk, Teun A. 2008. Discourse and Context: A Socio-cognitive Approach. Cambridge: Cambridge University Press.

van Dijk, Teun A. 2009. Society and Discourse: How Social Context Influence Text and Talk. Cambridge: Cambridge University Press.

Wijana, I Dewa Putu. 2015. On Ethnic Jokes in Indonesia. Journal of Languange and Literature; Vol. 15 No. 2, Hal. 103-110.

Wolfers, Solvejg, File, Kieran \&. Schnurr, Stephanie. 2017. "Just Because He's Black": Identity Construction and Racial Humour in A German U-19 Football Team. Journal of Pragmatics, 112, Hal. 83-96. doi: 10.1016/j.pragma.2017.02.003

Wawancara Andrik Purwnatoko, pegawai bank Jatim Wawancara Suryono, warga Sumenep Madura Wawancara Abdurrahman, warga Brongkal, Kabupaten Malang Wawancara Said Jazuli, warga Pagelaran, Kabupaten Malang 